\title{
Tribunal do júri virtual: em busca da harmonização entre as soluções emergenciais ocasionadas pela pandemia do novo coronavirus e a observância dos preceitos constitucionais
}

\begin{abstract}
Virtual jury court: seeking harmonization between the emergency solutions caused by the pandemic of the new coronavirus and the observance of constitutional precepts
\end{abstract}

\begin{abstract}
Ronald Pinheiro Rodrigues ${ }^{1}$
Instituto Brasileiro de Ensino, Desenvolvimento e Pesquisa - Brasília/DF, Brasil ronald.pinheiro.rodrigues@gmail.com http://lattes.cnpq.br/8946586928510245

https://orcid.org/0000-0002-8227-4309

Nigel Stewart Neves Patriota Malta2

Universidade Federal de Alagoas - Maceió/AL, Brasil nigelmalta@tjal.jus.br http://lattes.cnpq.br/3983490925456375

https://orcid.org/0000-0002-0181-4474
\end{abstract}

Resumo: O Poder Judiciário brasileiro tem buscado promover as devidas adequações às mudanças causadas pelo novo coronavírus (Sars-CoV-2), com a realização de audiências e diversos outros atos processuais, mediante instrumentos de videoconferência. Este artigo aborda a

1 Doutorando em Direito Constitucional pelo Instituto Brasileiro de Ensino, Desenvolvimento e Pesquisa (IDP). Mestre em Direito pela Faculdade Damas da Instrução Cristã (FADIC). Graduado em Direito pela Universidade Federal de Alagoas (UFAL). Advogado. Procurador Municipal. Professor Universitário.

2 Doutorando em Educação e Mestre em Direito pela Universidade Federal de Alagoas (UFAL). Bacharel em Direito pelo Centro Universitário Cesmac. Professor Universitário. Foi Diretor-Geral do Tribunal de Justiça do Estado de Alagoas (TJAL), onde atua como Chefe de Gabinete. 
proposta do Conselho Nacional de Justiça (CNJ) de virtualização, nesse período, das sessões do tribunal do júri, à luz dos preceitos constitucionais sobre a matéria. A problematização centra-se na busca pela harmonização entre as soluções emergenciais surgidas no contexto pandêmico com as diretrizes encartadas na Recomendação $n^{\circ}$ 62/2020 do referido órgão de controle interno do Poder Judiciário. Discutem-se questões variadas, com ênfase no debate constitucional, sobre critérios afetos ao tribunal do júri, como o prejuízo argumentativo, a proeminência do procedimento especial e a aplicabilidade das disposições legais de videoconferência ao rito sob análise, além daquelas atinentes ao sigilo das votações e da incomunicabilidade dos jurados, com apontamentos para medidas desencarceradoras. A partir de metodologia fundada em revisão de literatura especializada, com abordagem qualitativa, formula-se um juízo crítico acerca da inconstitucionalidade da pretensão de virtualização do procedimento especial do júri, proposta que se deu especialmente sob o pretexto inadequado de efetivação do princípio constitucional da razoável duração do processo.

Palavras-Chave: Tribunal do júri; Virtualização; Pandemia do novo coronavírus; Videoconferência; Júri virtual.

ABSTRACT: The Brazilian Judiciary has sought to promote the appropriate adaptations to the changes caused by the new coronavirus (Sars-CoV-2), with the holding of hearings and several other procedural acts, using videoconferencing instruments. This article addresses the proposal of the National Council of Justice (CNJ) for virtualization, during that period, of the sessions of the jury court, in the light of the constitutional precepts on the matter. The problematization focuses on the search for harmonization between the emergency solutions that arose in the pandemic context with the guidelines included in Recommendation $n^{\circ}$ 62/2020 of the referred internal control body of the Judiciary. Various issues are discussed, with emphasis on the constitutional debate, on criteria related to the jury's court, such as the argumentative prejudice, the prominence of the special procedure and the applicability of the legal provisions of videoconferencing to the rite under analysis, in addition to those related to secrecy of the votes and the incommunicability of the jurors, with notes for not incarceration measures. Based on a methodology based on a review of specialized literature, with a qualitative approach, a critical judgment is formulated about the constitutionality of the intention to virtualize the jury's special procedure, a proposal that took place especially under the adequate 
pretext of effect of the constitutional principle of reasonable duration of the process.

KEYwoRDs: Jury court; Virtualization; Pandemic of the new coronavirus; Video conference; Virtual jury.

\section{INTRODUÇÃO}

O tribunal do júri, previsto na Constituição Federal (CF) de 1988 como direito e garantia individual, tem por essência a participação dos membros integrantes do seio social em importante parcela de atuação do Poder Judiciário, como mecanismo de procedimentalização de julgamentos que incidem sobre os crimes dolosos contra a vida, matéria elementar à conjuntura civilizacional, com envergadura constitucional de cláusula pétrea.

Diante de seu sobrelevado jaez na sistemática do Poder Judiciário brasileiro, surge a idealização de sua virtualização como uma tentativa de nova formatação - de caráter supostamente provisório -, motivada pelo atual cenário da pandemia da Covid-19, que vem produzindo nefastos efeitos por todos os recantos do globo terrestre.

O Poder Judiciário brasileiro tem buscado promover as devidas adequações às mudanças causadas pelo novo coronavírus (COVID-19), com a realização de audiências e diversos outros atos processuais, mediante instrumentos de videoconferência. As novas tecnologias digitais estão sendo de grande valia para a compatibilização das atividades jurisdicionais que, diante da alta demanda processual, não podem restar paralisadas, especialmente por se tratar de algo que se afigura essencial.

Com efeito, vem sendo discutida no âmbito do Conselho Nacional de Justiça (CNJ) a provável implementação das atividades do tribunal do júri de maneira virtual, em que a proposta seria, de maneira sucinta, a realização do plenário através de plataforma digital de videoconferência. A problemática surge a partir daí, porquanto há grande discussão, na doutrina nacional, acerca da possibilidade de um tribunal do júri virtualizado, e dos seus consectários, notadamente os questionamentos sobre eventuais prejuízos ao réu. 
Embora não haja previsão para o fim das medidas de contenção da pandemia (isolamento social, quarentena e distanciamento social), e o consequente retorno às atividades presenciais, sob a justificativa da alta propagação do vírus causador da enfermidade epidêmica em locais que impliquem aglomeração de pessoas, a proposta de realizar o plenário do tribunal de júri por videoconferência tem provocado discussões acaloradas.

Trata-se de uma interpretação jurídica, em que será levado em consideração argumentos que sustentam a tese da ilegalidade da sessão do júri ser realizada por meio de videoconferência, bem como eventuais argumentos a favor ${ }^{3}$. Entre as argumentações despendidas, avista-se desde a impossibilidade de virtualização até a suscitação de sua inconstitucionalidade. Tais circunstâncias estão relacionadas especialmente à interpretação e à aplicabilidade dos princípios que emanam do texto constitucional e que perfazem as características do tribunal do júri, a dizer: a plenitude de defesa, o sigilo das votações e a soberania dos vereditos. Tema de inequívoca atualidade e relevância, a virtualização de procedimentos processuais encontra terreno fértil para discussões acadêmicas inovadoras, como é o caso da proposta de virtualização do tribunal do júri.

O objetivo deste artigo é enfrentar reflexivamente as propostas atuais do CNJ sobre a matéria, com o intuito de responder ao seguinte questionamento: no cenário da problematização, seria possível - e de que forma - harmonizar soluções emergenciais advindas do contexto pandêmico com os preceitos constitucionais sobre o tribunal do júri?

A partir do desenvolvimento teórico-argumentativo sobre a capacidade ou não de um tribunal do júri virtual, buscar-se-á a produção de uma análise dos posicionamentos doutrinários já lançados à luz dos atos normativos respectivos, com esteio na revisão da literatura especializada levantamento bibliográfico e histórico -, abordagem sob a perspectiva qualitativa e sem a pretensão de esgotar a matéria, mas tão só de prestar um contributo aos estudos no âmbito do direito processual penal.

3 CRUZ, Rogerio Schietti; LUNARDI, Fabrício Castagna; GUERREIRO, Mário Augusto Figueiredo de Lacerda. Tribunal do júri com apoio de videoconferência: pela ética do discurso. Consultor Júridico, 2020. 


\section{O CENÁRIO DA PANDEMIA E A PROPOSTA DE REALIZAÇÃo DE SESSÕES VIRTUAIS DO TRIBUNAL DO JÚRI}

O mundo está vivenciando uma situação de extrema excepcionalidade com a chegada do vírus causador da Covid-19, doença que vem protagonizando um dos maiores surtos epidemiológicos já registrados, deixando um rastro de mortes no mundo. Em vista disso, o mundo inteiro foi obrigado a adequar-se às medidas preventivas e de isolamento, a fim de minorar a propagação do vírus até que se produza uma vacina ou venha a se descobrir um protocolo medicamentoso eficiente, o que mudou drasticamente o cenário econômico e político do mundo, e principalmente do Brasil, que sofre grande pressão com a crise econômica e o colapso no seu sistema de saúde.

Não só a economia e a saúde amargam os impactos da pandemia, mas o Poder Judiciário teve de passar por uma remodelação no seu modo de atuar, sobremodo no que diz respeito à realização de audiências presenciais. Ademais, a pandemia repercutiu no aumento do número de demandas judiciais - especialmente no âmbito criminal -, sobrecarregando ainda mais o Judiciário - já deficitário -, o qual é acionado para os problemas que surgem nesse período.

Percebe-se que, ainda que com grande dificuldade, o judiciário vem encontrando formas de exercer sua atividade sem interrupção. Importante instrumento é a tecnologia, que vem auxiliando o Poder Público de forma grandiosa. E mais, ainda que o atendimento ao público tenha sido restrito, a judiciário, através do Conselho Nacional de Justiça, vem minimizando os impactos editando resoluções que visam orientar o magistrado nesse período extraordinário ${ }^{4}$. E mais, não se pode deixar de falar dos impactos ocasionados pela pandemia, tais como prazos suspensos, audiências presenciais canceladas e sessões de julgamentos suspensas. Tudo isso gerou grande atraso na atividade jurisdicional, em que o público foi o maior prejudicado.

4 Sobre isso: LIBER, Gabriel Henrique Araújo; RAINHO, Murilo Teixeira. Audiências virtuais na pandemia do coronavírus e seus reflexos no âmbito dos juizados especiais cíveis. ETIC, v. 16, n. 16, 2020. 
A fim de evitar o acúmulo de demandas processuais e dar fluidez ao trabalho, o Poder Judiciário lançou mão de instrumentos tecnológicos, com a chancela do CNJ, o qual tornou cabível a realização de audiências através de videoconferência. Tal fato foi ratificado com a edição da Resolução $n^{0} 314 / 2020$, que estabeleceu diretrizes gerais para o trabalho remoto de servidores em geral e magistrados, mediante a realização de atos processuais através de meios digitais.

A medida tomada pelo CNJ evitou que o Poder Judiciário entrasse em colapso - e consequentemente houvesse um desabastecimento considerável da função jurisdicional, o que seria de extrema prejudicialidade à sociedade -, tornando necessária a virtualização dos procedimentos processuais em todo o país. Os operadores do direito, no momento extraordinário que se atravessa, tiveram de se transformar para garantir a efetiva entrega da prestação jurisdicional, sem, contudo, prejudicar os direitos fundamentais dos indivíduos - com ênfase no acesso à justiça -, nem comprometer a celeridade processual.

Além da Resolução n ${ }^{0} 314 / 2020$, já mencionada, vale destacar que o CNJ também editou a Recomendação no 62/2020, trazendo a possibilidade da audiência virtual nos casos criminais que envolvem acusados presos e estabelecendo diretrizes de desencarceramento no período, por motivação sanitária. O citado órgão de controle interno do Poder Judiciário, no início da pandemia, vislumbrou uma proposta de realização de sessões do tribunal do júri de forma virtual, através de mecanismos de videoconferência, a fim de que fosse garantida a celeridade processual e a efetivação do princípio da duração razoável do processo ${ }^{5}$.

A despeito disso, importa mencionar que as sessões do tribunal do júri tornaram-se de impossível realização, naturalmente em face das medidas de contenção de contágio, tendo inicialmente, inclusive, o próprio órgão censor do Poder Judiciário emanado proibição específica para a realização das sessões, sob o fundamento da proteção à saúde pública.

Todavia, deve-se ter em mente que as sessões do tribunal do júri não podem ser suspensas indefinidamente, já que o acusado tem o

5 BRASIL. Conselho Nacional de Justiça. Disponível em: <https://www.cnj.jus. $\mathrm{br} /$ tribunal-do-juri-cnj-apresenta-ao-legislativo-propostas-para-desburocratizar-julgamentos/>. Acesso em: 22 de dez. 2020. 
direito constitucional de ser julgado em tempo razoável, não podendo ser prejudicado por circunstância a que não deu causa, situação que se agrava de forma considerável quando o réu aguarda o julgamento encarcerado.

Posteriormente, surge a proposta de realização das sessões do tribunal do júri por meio de mecanismos de videoconferência, tendo como fundamento a maior efetividade nos julgamentos de crimes dolosos contra a vida. Para o CNJ, o tribunal do júri é um procedimento excessivo e formalista, o que prejudica a celeridade processual e a duração razoável do processo.

Com efeito, o fundamento central da proposta se alicerça em alguns preceitos constitucionais, tais como a duração razoável do processo e a celeridade processual. Para os que sustentam essa possibilidade que chegou a ser ventilada em minuta de Resolução encaminhada com voto de aprovação por parte do Conselheiro Relator, o que conta com o apoio da Associação dos Magistrados Brasileiros (AMB) -, o contexto da pandemia em que o país se encontra e o excessivo número de réus presos que aguardam julgamento fazem exsurgir uma situação alarmante, o que legitimaria a adoção, por parte do Poder Judiciário, de medidas extraordinárias (Ato Normativo $\mathrm{n}^{\circ}$ 0004587-94.2020.2.00.0000 - CNJ).

Em contrapartida, parcela considerável da literatura especializada prontamente rechaçou a proposta, sob a alegação de inobservância de preceitos constitucionais. Diante do embate travado, este escorço acadêmico se propõe ao exame contrastado dos argumentos espargidos, em busca de eventual harmonização entre as proposições.

\section{A EMERGENCIALIDADE DA SOLUÇÃo APONTADA E A INOBSERVÂNCIA DOS PRECEITOS CONSTITUCIONAIS SOBRE O TRIBUNAL DO JÚRI}

A Constituição tem por finalidade estabelecer, organizar e ser o sustentáculo de algo que se pretende instituir, a dizer, a conjuntura estatal, representada na ideia republicana de ordenamento jurídico. Por isso, especialmente em seus elementos orgânicos, há um detalhado arranjo dos poderes, com a limitação de seus exercícios, devido à necessidade de se observar a soberania popular. ${ }^{6}$

6 Sobre isso: MELCHIOR, Antonio Pedro. Crítica científica de "Redefinindo o trânsito em julgado a partir da soberania dos veredictos: a coisa julgada 
Nessa perspectiva, a par de uma interpretação teleológica da CF, o tribunal do júri intenta permitir que os indivíduos participem ativamente na efetivação do Estado Democrático de Direito. Pensando na garantia e na efetivação dos direitos fundamentais, a Carta Política instituiu o tribunal do júri como garantia fundamental e sob proteção constitucional. ${ }^{7}$

Como direito fundamental, o tribunal do júri deve ser visto como uma garantia necessária à efetivação dos direitos do indivíduo, tais como a dignidade da pessoa humana e o direito à vida, entre outros. ${ }^{8} \mathrm{Na}$ visão de Lenio Streck, o Estado Democrático de Direito alicerça-se em dois pilares: i) o pilar da democracia, sem a qual há inibição ao respeito à concretização de direitos; e ii) o pilar dos direitos fundamentais, que restaria prejudicado sem o pilar da democracia, porquanto a ausência do primeiro configuraria fator impeditivo à "realização dos direitos fundamentais-sociais", bem assim "não há direitos fundamentais-sociais - no sentido que lhe é dado pela tradição", de modo que "há assim uma copertença entre ambos" - democracia e direitos fundamentais. ${ }^{9}$

Por isso, qualquer instituição inovadora de procedimentos pertinentes ao tribunal do júri deve guardar estrita observância aos preceitos constitucionais, mesmo que o argumento preponderante esteja atrelado à necessidade de adequação do Poder Judiciário ao cenário da pandemia. As sessões do tribunal do júri são repletas de formalidades, necessárias para a observância dos seus princípios pilares, motivo pelo qual adentraremos nas imbricações acerca da compatibilidade da proposta com as disposições constitucionais, bem como no contexto de aplicabilidade da normatização infraconstitucional que dialoga com a matéria.

parcial no tribunal do júri”. Revista Brasileira de Direito Processual Penal, Porto Alegre, vol. 6, n. 2, p. 1059-1078, mai./ago. 2020; RODRIGUES, Paulo Gustavo. Redefinindo o trânsito em julgado a partir da soberania dos veredictos: a coisa julgada parcial no tribunal do júri. Revista Brasileira de Direito Processual Penal, Porto Alegre, vol. 6, n. 2, p. 873-910, mai./ago. 2020.

7 RANGEL, Paulo. Tribunal do júri: visão linguística, histórica, social e jurídica. São Paulo: Atlas, 2018, p. 276.

8 TUBENCHLAK, James. Tribunal do júri: contradições e soluções. Rio de Janeiro: Forense, 1991, p. 69.

9 STRECK, Lenio Luiz. Jurisdição constitucional e hermenêutica: uma nova crítica do direito. Rio de Janeiro: Forense, 2004, p. 151. 


\subsection{BREVES CONSIDERAÇÕES SOBRE A INCONSTITUCIONALIDADE FORMAL E MATERIAL DA PROPOSTA}

Preliminarmente, verifica-se que a proposta do CNJ para realizar as sessões do tribunal do júri virtual não encontra amparo na legislação vigente. Ao revés, o que se visualiza, de pronto, é a ausência de competência legislativa para tratar sobre matéria de direito penal ou direito processual penal, conforme interpretação advinda da própria CF, em seu art. 22, inciso I, que destina privativamente as matérias em referência ao âmbito do Poder Legislativo da União.

Por ser órgão administrativo integrante do Poder Judiciário, o CNJ não possui competência para legislar sobre matéria processual, inclusive sobre uma garantia instituída pela CF. O artigo 92, inciso I-A, da Carta Magna deixa claro que o CNJ faz parte do Poder Judiciário, devendo ser visualizada, tal disposição, como uma limitação à atuação do órgão. Somente seria possível se houvesse delegação por parte da União através de Lei complementar, o que não houve. Sobre o assunto, Novelino explica que:

A competência privativa pode ser objeto de delegação. Inspirada no modelo germânico, a Constituição permitiu que a União, por lei complementar, autorize os Estados a legislar sobre questões específicas das matérias de sua competência privativa (artigo 22, parágrafo único) $)^{10}$

O procedimento do tribunal do júri, tratando-se de competência privativa da União, aloca-se na esfera de competência legislativa do Congresso Nacional, cabendo ao Supremo Tribunal Federal a interpretação final da CF. Se tal atribuição fosse exercida pelo CNJ, visualizar-se-ia sua atuação como verdadeiro legislador positivo, o que apresenta dissonância com a ideia de separação e equilíbrio dos Poderes da República.

A CF institui as matérias que cabem ao CNJ, consoante disposições previstas no art. 103-B, $\S 4^{\circ}$, incisos I a VII, de modo que não figura, neste rol, qualquer regramento acerca de atuação no sentido proposto.

10 NOVELINO, Marcelo. Direito Constitucional. Rio de Janeiro: Forense, 2009, p. 543 . 
Com efeito, a partir desse raciocínio, não poderia o CNJ fundamentar sua proposta na duração razoável do processo quando não houver observância ao próprio devido processo (constitucional) legal, previsto como regra matriz na CF e pilar para todos os outros princípios processuais penais e constitucionais, infraconstitucionais, expressos ou implícitos.

Ainda que em tempos excepcionais, o devido processo legal deve ser observado, tendo em vista sua natureza garantidora. Nestor Távora e Rosmar Alencar discorrem acerca do referido princípio, assentando a consagração da tipificação do processo com a completude de seus atos essenciais. Para os mencionados autores, "a pretensão punitiva deve perfazer-se dentro de um procedimento regular, perante a autoridade competente, tendo por alicerce provas validamente colhidas, respeitando-se o contraditório e a ampla defesa". ${ }^{11}$

Por isso, não basta alegar a situação excepcional da pandemia e a duração razoável do processo para propor as sessões do tribunal do júri de forma virtual; é necessário, além disso, analisar eventuais violações em que consequentemente tal formato incorrerá, inclusive a inconstitucionalidade da proposta, uma vez que o órgão administrativo não é competente para legislar sobre os procedimentos, tampouco para alterá-los. ${ }^{12}$

Nessa linha, forçoso o reconhecimento, $a b$ initio, diante de motivação formal, da impossibilidade da proposta, por recair sobre ela a pecha da inconstitucionalidade por vício de incompetência para tratar sobre a matéria, o que, no entanto, não encerra o debate sobre as questões substanciais que permeiam o presente estudo.

\subsubsection{As GARANTIAS DO SIGILO DAS VOTAÇÕES E DA INCOMUNICABILIDADE DOS JURADOS}

Outra problemática enfrentada com a proposta das sessões em formato virtual é a observância do sigilo das votações, princípio norteador

11 TÁVORA, Nestor; ALENCAR, Rosmar Rodrigues. Curso de direito processual penal. Salvador: JusPodivm, 2019, p. 88.

12 SIMÃO, Diego de Azevedo. Júri por videoconferência é inconstitucional. Consultor Jurídico. Disponível em: <https://www.conjur.com.br/2020-jun-24/diego-simao-juri-videoconferencia-inconstitucional>. Acesso em: 26 jul. 2020. 
e essencial para a formalidade do tribunal do júri ${ }^{13}$. Demais disso, verifica-se que a realização das sessões de modo virtual enfrenta óbice de grande magnitude, já que extenua qualquer controle quanto à incomunicabilidade dos jurados, a teor do que dispõe o art. 466 , $\S \S 1^{\circ}$ e $2^{\circ}$, do Código de Processo Penal (CPP).

A existência da garantia do sigilo das votações reveste-se de natureza defensiva ao próprio Conselho de Sentença, blindando-o contra a violação de seu próprio voto. Com o fito de acautelar a formação livre da convicção dos juízes leigos, repele-se a eclosão de quaisquer origens de constrangimento, defluindo de tal garantia a salvaguarda da formação e da manifestação da sentença. ${ }^{14}$

Malgrado o sigilo das votações, em tese, permaneça no formato virtual, não há como garantir a incomunicabilidade do Conselho de Sentença, uma vez que não haverá fiscalização para evitar o contato entre o conselho. Decerto, a determinação legal de incomunicabilidade dos julgadores leigos obtempera a vedação de quaisquer manifestações da posição dos juízes leigos, evitando-se a influência aos demais jurados por ocasião da tomada de decisão, devendo ser objeto de advertência "pelo juiz no momento do sorteio para composição do conselho de sentença e [...] certificada pelo oficial de justiça, além de que sua violação acarreta nulidade do julgamento". ${ }^{15}$

Sem que haja um controle acerca da incomunicabilidade da comissão e do sigilo das votações, sublinha-se que haverá violação ao sistema adotado pelo ordenamento jurídico penal, qual seja o sistema da íntima convicção do Conselho de Sentença, em que a incomunicabilidade dos jurados e o sigilo traduzem os instrumentos de proteção

13 RANGEL, Paulo. Tribunal do júri: visão linguística, histórica, social e jurídica. São Paulo: Atlas, 2018, p. 213.

14 PORTO, Hermínio Alberto Marques. Júri: procedimentos e aspectos do julgamento, questionários. São Paulo: Saraiva, 2005, p. 22.

15 Sobre isso: VASCONCELLOS, Vinicius Gomes de; GALÍCIA, Caíque Ribeiro. Tribunal do júri na justiça criminal brasileira: críticas e propostas de reforma para a restituição de sua função de garantia no processo penal democrático. Revista Eletrônica de Direito Processual, v. 13, n. 13, p. 1-28, 2014. 
da livre formação da opinião dos jurados, que não deverão sofrer influência alguma. ${ }^{16}$

Daniel Bialski afirma ser de difícil verificabilidade o respeito ao princípio em comento, especialmente pelo fato de que não se deve esquecer que a incomunicabilidade significa que "os jurados não podem conversar com outras pessoas sobre o caso, nem debater algo relacionado ao que foi dito no julgamento" ${ }^{17}$, o que torna praticamente impossível de controle e aferição quando se trata da realização do ato em ambiente virtual.

Deste modo, vislumbram-se inúmeras conjecturas maculadoras do processo em demasiado prejuízo à defesa, a qual será submetida aos riscos da quebra da incomunicabilidade da comissão e quanto ao sigilo nas votações ${ }^{18}$, pois o Poder Judiciário, da forma como foi proposta, mostra-se impossível fiscalizar todos do conselho, ou mesmo de garantir concretamente que não haverá qualquer quebra.

\subsection{Prejuízo ao EXERCícIo da ARGUMENTAÇÃo E O DIREITO À AUTODEFESA}

Além das mais variadas ofensas aos direitos constitucionais penais e processuais penais, as sessões realizadas virtualmente acarretam prejuízo ao exercício da argumentação, considerando que, ainda que seja utilizada, em grande parte da atuação no âmbito jurídico, a técnica - que por diversas vezes prepondera no âmbito do tribunal do júri -, o conselho também leva em consideração a postura dos tribunos, por ocasião de suas exposições orais, em que há a transmissão conjugada de fatores emocionais, retóricos e jurídicos ${ }^{19}$.

16 Sobre isso: LUCINDO, Micheline Amorim. A incomunicabilidade dos jurados no tribunal do júri brasileiro. Monografia em Direito. Centro Universitário de Brasília (UniCEUB) Brasília, p. 1-54, 2009.

17 NUÑEZ, Izabel; NEWTON, Eduardo Januário. O que será do tribunal do júri após a pandemia da covid-19? Consultor Jurídico (ConJur). Disponível em: <https://www.conjur.com.br/2020-mai-12/newton-nunez-tribunal-juri-pandemia>. Acesso em: 26 jul. 2020.

18 GOMES, Márcio Schlee. Sigilo das votações e incomunicabilidade: garantias constitucionais do júri brasileiro. Revista do Ministério Público, Porto Alegre, $\mathrm{n}^{\mathrm{0}} 67$, p. 35-59, set. 2010.

19 Ibidem. 
O fenômeno jurídico, em sua vastidão de complexidades, pode ser compreendido, em algumas de suas definições operacionalmente úteis, a partir de concepções diversificadas, a exemplo do que se pondera sobre a arte e a técnica no direito, duas significações que se entrelaçam de forma bastante contundente quando o assunto é o tribunal do júri. ${ }^{20}$

Enquanto arte, o exercício do direito se propõe à missão de convencer aqueles que se incumbem do dever decisório, a exemplo do emprego do modelo de retórica aristotélica baseada no ethos, no páthos e no $\operatorname{logos}^{21}$, quando argumentativamente se constroem discursos baseados nas premissas do tribuno ou réu digno de fé, permeado por circunstâncias apaixonantes e/ou baseadas na lógica silogística, sem olvidar outros recursos que venham a lograr emoções naqueles a quem se direciona a atividade jurídica. ${ }^{22}$

A técnica diz respeito ao manejo adequado do "conjunto de meios e de procedimentos que tornam prática e efetiva a norma jurídica" ${ }^{23}$, a par das disposições que compõem o ordenamento jurídico, reportando-se às fontes do direito em busca dos meios disponíveis no direito positivo para o alcance de seus desideratos.

No tribunal do júri - e na atuação diária, de modo geral -, arte e técnica (e ciência) caminham pari passu ${ }^{24}$. Entrementes, tem-se, ontologicamente, por ocasião do processo de tomada de decisão por parte dos juízes leigos - jurados -, a prevalência do direito em sua acepção arte, sobretudo pelo fato de essa decisão ser regida pela íntima convicção dos respectivos julgadores, tornando despicienda qualquer fundamentação ${ }^{25}$.

20 Sobre isso: MACIEL, José Fábio Rodrigues (coord.). Formação humanística em direito. São Paulo: Saraiva, 2012.

21 AMARAL, Sérgio Tibiriça; PEREIRA, Allan Aparecido Gonçalves. A arte do convencimento e o tribunal do júri. Revista Intertemas. v. 15, n. 15, p. 1-68, 2008.

22 NASCIMENTO, Joelson Santos. A relação entre lógica, páthos e ethos na arte retórica de Aristóteles. Anais de Filosofia Clássica, vol. 9, $\mathrm{n}^{\circ}$ 17, 2015.

23 NADER, Paulo. Introdução ao estudo do direito. Rio de Janeiro: Forense, 2014, p. 214.

24 AMARAL, Sérgio Tibiriça; PEREIRA, Allan Aparecido Gonçalves. A arte do convencimento e o tribunal do júri. Revista Intertemas. v. 15, n. 15, p. 1-68, 2008.

25 OLIVEIRA, Heitor Moreira de; ATAÍDES, Maria Clara Capel de. Hermenêutica e Direito: Um olhar fenomenológico da performance. Anais do IV Congresso 
Não estar-se-á falando que o tribunal do júri é mero espetáculo, considerando que trata da liberdade do acusado. O que o artigo visa demonstrar é que, além da técnica utilizada, tais como a utilização de teses e argumentos favoráveis ao acusado, a defesa e o ministério público utilizam das emoções dos julgadores para garantir que sua tese seja vencedora.

Com efeito, ainda que a tecnologia esteja auxiliando bastante o Poder Judiciário na pandemia, como visto na definição alhures, não se pode perder de vista que o tribunal do júri não só é composto pela técnica processual das partes, mas toda a emoção presenciada pelos jurados, a postura e os gestos corporais exercem influência no momento em espeque, de modo que não se pode olvidar o fato de que os juízes naturais da causa se deixam levar pela voz e pelos demais elementos desse contexto, emanados dos atores processuais. ${ }^{26}$ São detalhes que os meios tecnológicos não conseguem captar em sua plenitude, pois há limitações evidentes. ${ }^{27}$

$\mathrm{O}$ direito à defesa do acusado deve ser observado e garantido com todas as formalidades de praxe que naturalmente circundam a sistemática presencial do tribunal do júri ${ }^{28}$, uma vez que haverá a presença de todos os envolvidos, bem como das testemunhas, e os jurados podem presenciar, de fato, a emoção vivenciada pelas partes, além de outros sentimentos e técnicas apropriadas, que só podem exercer efetivamente o seu desiderato de maneira presencial.

A esse respeito, tem-se o escólio de Marcelo Leal, que sustenta a necessidade da manutenção da sistemática presencial, sobretudo em razão de os jurados levarem em consideração "o calor do momento e as emoções do autor e da vítima”, pois os julgadores constitucionalmente atribuídos aos crimes dolosos contra a vida não se baseiam apenas no

de Fenomenologia da Região Centro-Oeste (eixo temático 5: Fenomenologia, arte e cultura). Goiânia: NEPEFE/FE-UFG, vol. 1, n. 1. 2011.

GARAPON, Antoine. Bem julgar: ensaio sobre o ritual judiciário. Lisboa: Instituto Piaget, 1997, p.72.

MONTEIRO, Paloma Abreu. O corpo nos rituais jurídicos: cultura, vestimenta e tatuagem nos tribunais do júri e varas criminais do Rio de Janeiro. Dissertação de mestrado. Programa de Pós-Graduação Stricto Sensu em Direito Constitucional da Universidade Federal Fluminense - PPGDC/UFF, 2015.

LOPES JR., Aury. Direito processual penal. 16. ed. São Paulo: Saraiva, 2019, p. 206. 
tecnicismo e "fundam seus julgamentos nos sentidos, todos eles. A voz do advogado e sua entonação, a presença do réu em plenário, a emoção passada pelas testemunhas e outros sentimentos que só presencialmente se pode adquirir". ${ }^{29}$

É evidente que a ocorrência das sessões através de videoconferência demandará prejuízos em escalas de elevado grau, sobremaneira ao acusado, uma vez que o contato imediato entre o réu e os jurados nesses momentos é imprescindível, dada a importância de o conselho sentir as emoções transmitidas pelas partes, o que implicitamente se arraiga às fundações do sistema do júri. Portanto, deve ser respeitada a sua razão de ser..$^{30}$

A ausência de contato entre as partes limita as suas possibilidades argumentativas, uma vez que o meio tecnológico não possui o condão de transmitir em sua totalidade as características próprias da ideia do direito-arte. Como consectário lógico, percebe-se que a ampla defesa princípio estampado na CF - ampara a defesa da incompatibilidade da proposta, na medida em que haverá restrição ao exercício das práticas envolvidas e que perfazem o direito de defesa.

Além disso, visualiza-se que o próprio direito à autodefesa - isto é, a "defesa de um direito (no caso a liberdade) feita pelo próprio titular do direito"31 - restará minorado, porquanto ainda que participando por videoconferência, o acusado não terá como exercitar com amplitude seu relevante papel de contribuir com suas versões e emoções sobre o fato $^{32}$, o que configura uma possibilidade concreta de modificação da convicção da junta.

29 NUÑEZ, Izabel; NEWTON, Eduardo Januário. O que será do tribunal do júri após a pandemia da covid-19? Consultor Jurídico (ConJur). Disponível em: $<$ https://www.conjur.com.br/2020-mai-12/newton-nunez-tribunal-juri-pandemia>. Acesso em: 26 jul. 2020. Ibidem.

${ }^{31}$ Sobre isso: PICCOLO, André Gustavo Bevilacqua. A supremacia da autodefesa: os limites da defesa técnica no processo penal constitucional. Revista da Defensoria Pública da União, v. 1, n. 1, 2018.

32 BULOS, Lammêgo Uadi. Constituição federal anotada. São Paulo: Saraiva, 2002, p. 1456. 
Com o devido acatamento aos entendimentos dissonantes, a permissibilidade para que o tribunal do júri seja considerado um procedimento de julgamento meramente técnico é de enorme nocividade, sem levar em consideração a importância do aspecto artístico no seu contexto.

Sobre isso, sobreleva-se a avaliação de Daniel Bialski, ao apontar que o julgamento presencial possui contextos extremamente diferenciados dos atos praticados no modo virtual, pois "detalhes comportamentais podem fazer a diferença, seja no olhar ou reação”, o que influi na forma como se valoram as posturas, os gestos e as exposições orais ${ }^{33}$. Para o citado autor, que conclui seu traçado pela impossibilidade de realização das sessões do júri em formato virtual, tem-se uma enorme diferenciação entre as formas presencial e virtual, uma vez que "virtualmente tudo se altera em todos os aspectos e as emoções não são tão perceptíveis”. Por fim, ressalta a impossibilidade de se garantir um julgamento íntegro e justo. ${ }^{34}$

Nota-se que não é necessária tão somente a efetivação da defesa técnica, através de uma argumentação completa, que repasse as emoções trazidas pelas partes, mas também a autodefesa, que pode ser representada pelo direito de presença. ${ }^{35}$ Tal direito consiste na possibilidade de o réu tomar posição sobre o material produzido, sendo-lhe garantida, inclusive, a imediação com o defensor, o juiz e as provas. ${ }^{36}$

Sobre o direito à autodefesa, André Nicolitt arremata:

O direito de se defender perante o juiz não pode ser exercido plenamente se entre homens existe uma máquina. O juiz, que

33 BIALSKI, Daniel. Tribunal do Júri por videoconferência inviabiliza defesa, avaliam advogados. Consultor Jurídico, 2020. Disponível em: <https://www.conjur.com.br/2020-jul-06/tribunal-juri-videoconferencia-inviabiliza-defesa-avaliam-advogados>. Acesso em: 26 jul. 2020.

BIALSKI, Daniel. Tribunal do Júri por videoconferência inviabiliza defesa, avaliam advogados. Consultor Jurídico, 2020. Disponível em: <https://www.conjur.com.br/2020-jul-06/tribunal-juri-videoconferencia-inviabiliza-defesa-avaliam-advogados>. Acesso em: 26 jul. 2020.

PERELMAN, Chaïm; e OLBRECHTS-TYTECA, Lucie. Tratado da argumentação: a nova retórica. Tradução: Maria Ermantina de Almeida Prado Galvão. São Paulo: WMF Martins Fontes, 2014, p. 363.

36 Sobre isso: ALVES, Danielle Peçanha; MASTRODI NETO, José. Tribunal do júri e o livre convencimento dos jurados. Revista Brasileira de Ciências Criminais, v. 116, p. 1-19, 2015. 
não raro se esquece de sua condição humana e da condição humana daquele que está sob seu jugo, que não raro deixa de ver o homem que está atrás do número dos autos, com maior facilidade ainda se perderá na insensibilidade quando entre ele e o homem em julgamento estiver uma máquina que apenas aproxima duas dimensões muito distantes. ${ }^{37}$

Tal problemática ainda mais se agrava quando envolve réus presos, em que há o direito de presença garantido ao acusado, sob pena de suspensão do julgamento, conforme dispõe a regra do art. 457 do CPP. As sessões por meio de videoconferência não garantirão a amplitude da defesa, haja vista a inobservância de variadas questões que obstam a ampla possibilidade de defesa, incluindo o direito de autodefesa, que compreende também o direito de presença.

\section{ESPECIALIDADE DO RITO DO JÚRI E INAPLICABILIDADE DAS DISPOSIÇÕES DE VIDEOCONFERÊNCIA PREVISTAS NA LEGISLAÇÃO PROCESSUAL}

Diz a regra estatuída no art. $2^{\circ}, \S 2^{\circ}$, da Lei de Introdução às Normas do Direito Brasileiro (LINDB), que a novel legislação que versa sobre matéria preexistente de forma especial não modifica nem revoga a lei que já habitava anteriormente o ordenamento jurídico. Sob a ótica das lições preliminarmente apreendidas nos estudos jurídicos, a exegese aplicada a este dispositivo guarda relação com a ideia de impossibilidade de contradições e incoerências no ordenamento jurídico, bem assim com os aprofundados estudos doutrinários sobre os mecanismos de resolução das falsas antinomias. ${ }^{38}$

A partir disso, tem-se que é possível a coabitação de normas materialmente conflitantes, pois destinadas a aplicabilidades diversas. Estatui-se, a partir dessa premissa, o princípio da especialidade, que figura como importante sustentáculo da teoria do ordenamento jurídico,

37 NICOLITT, André. Manual de processo penal. Belo Horizonte: D’Placido, 2018, p. 735.

38 BOBBIO, Norberto. Teoria do ordenamento jurídico. 6. ed. Trad. Maria Celeste C. J. Santos. Brasília: Universidade de Brasília, 1995, p. 81. 
conferindo harmonia entre as legislações que, indiscutivelmente, têm suas respectivas interpretações e aplicações destinadas às situações especificamente interligadas com sua justificativa e razão de existir. ${ }^{39}$

Portanto, com fundamento no princípio da especialidade, a doutrina e a legislação processual penal consideram o júri como um rito de procedimento especial, no qual devem ser observadas todas as regras apropriadas. É evidente que as disposições previstas para o procedimento comum não se revelam, a priori, aptas a ensejar sua aplicação descomedida, como é o caso do interrogatório através de videoconferência na segunda fase - judicium causae - do rito especial em testilha.

Essa conjuntura de ideias nos leva à assertiva de que não se pode basear a realização das sessões virtuais do tribunal do júri na previsão que possibilita ao interrogatório ser realizado mediante videoconferência no procedimento comum.

Acerca da especialidade do tribunal do júri, assim decidiu a Quinta Turma do Superior Tribunal de Justiça (STJ), por ocasião do julgamento do Recurso Ordinário em Habeas Corpus nº 52.086/MG:

Os artigos 406 e seguintes do Código de Processo Penal regulamentam o procedimento a ser seguido nas ações penais deflagradas para a apuração de crimes dolosos contra a vida, assim, rito especial em relação ao comum ordinário, previsto nos artigos 394 a 405 do referido diploma legal. Por conseguinte, e em estrita observância ao princípio da especialidade, existindo rito próprio para a apuração do delito atribuído ao recorrente, afastam-se as regras do procedimento comum ordinário, previstas no Código de Processo Penal, cuja aplicação pressupõe, por certo, a ausência de regramento específico para a hipótese.

O julgado acima mencionado, que foi retirado de uma breve análise jurisprudencial no site do Superior Tribunal de Justiça, reafirma a necessidade de observar as regras do tribunal do júri, em que eventual mitigação na realização da sessão virtual poderá ocasionar violação às garantias processuais penais. Ainda que o CPP estabeleça a possibilidade de

39 NADER, Paulo. Introdução ao estudo do direito. Rio de Janeiro: Forense, 2014, p. 15. 
interrogatório por videoconferência no procedimento comum ordinário, não cabe tal interpretação extensiva ao tribunal do júri, ante uma série de garantias e direitos que devem ser observados através da formalidade do procedimento, além de configurar manifesto prejuízo ao acusado, ensejador da atração da cláusula pas de nullité sans grief, no sentido de afirmar o reconhecimento da nulidade do ato por gerar situação em detrimento do acusado. ${ }^{40}$

Aury Lopes também leciona acerca da impossibilidade de interpretação extensiva ou analógica nas formalidades do tribunal do júri, pois as regras trazidas pela CF e pelo CPP asseguram não só a especialidade do júri, mas também as garantias instituídas por este. Para o festejado autor, a sistemática legal do júri "está desenhada nos arts. 406 a 497 do CPP, tendo sido substancialmente alterada pela Lei $\mathrm{n}^{0} 11.689 / 208$. A competência do júri é assim muito bem definida no art. $74, \S 1^{\circ}$, de forma taxativa e sem admitir analogias ou interpretação extensiva. ${ }^{41}$

As lições de Paulo Rangel também são enfáticas:

No júri, o contato pessoal dos jurados com as testemunhas e o réu é fundamental para que possam ser captadas as reações deste às perguntas que lhe são formuladas. Ademais, a virtualidade do interrogatório do réu lhe retira a possibilidade ter contato presencial com os jurados, que são os juízes naturais da causa. ${ }^{42}$

Com efeito, evidencia-se que as regras concernentes ao procedimento comum ordinário, no que diz respeito ao interrogatório por videoconferência, não devem ser ampliadas ao procedimento do júri, o qual trata de matéria de maior complexidade e especificidade.

Aqui a maior obstaculização à possibilidade de realização das sessões do tribunal do júri através de videoconferência - em virtude das especificidades do procedimento e em razão de o júri ter como principal defesa do réu as idiossincrasias que envolvem a liturgia com a exposição

40 ALENCAR, Rosmar Rodrigues. Teoria da nulidade no processo penal. São Paulo: Noeses, 2016, p. 139.

41 LOPES JR., Aury. Direito processual penal. São Paulo: Saraiva, 2020, p. 1.243.

42 RANGEL, Paulo. Tribunal do júri: visão linguística, histórica, social e jurídica. São Paulo: Atlas, 2012, p. 125-127. 
de emoções pelas partes - reside na impossibilidade do contato presencial dos julgadores com as testemunhas e com o réu, situação que resta especificada na legislação e amparada na literatura processualista especializada sobre a especialidade do rito do júri. Nesse contexto, expõe Iorio Forti:

O júri popular foi criado para julgar os crimes de emoção, sentimentais, de paixão, e não bandidos de alta periculosidade. $\mathrm{O}$ tribunal do júri sempre serviu para um tipo de criminalidade em cidade pequena, onde a comunidade conhece as circunstâncias do fato, o próprio acusado. ${ }^{43}$

Ante tais particularidades, o tribunal do júri não pode ser visto como mero julgamento técnico, nem abrangido por outras tonalidades que envolvem a atuação dos profissionais do direito e das próprias partes envolvidas nos feitos de sua competência. É evidente que o julgamento do júri popular é dotado de características peculiares e que as regras previstas para o procedimento comum ordinário, quando incompatíveis com o procedimento do júri, não devem ser utilizadas, como é o caso da possibilidade de videoconferência e - mutatis mutandis - de sessões virtuais.

As sessões virtuais acabarão ofendendo não só as garantias previstas para o tribunal do júri, tornando o julgamento ainda mais oneroso para o réu, que terá a plenitude de defesa reduzida. Urge salientar que a proposta do CNJ não encontra substrato de plausibilidade para a sua concretização, seja pela ausência de competência para legislar sobre direito processual penal, seja em virtude de inúmeras violações às garantias constitucionais que um tribunal do júri virtual poderia acarretar.

Não nos parece razoável a tentativa de ampliar regras que são próprias do procedimento comum ordinário e inaplicáveis ao procedimento do júri, sob a alegação da duração razoável do processo. Esta, como garantia constitucional voltada também aos acusados, não pode ser interpretada às avessas, para representar uma restrição dos direitos defensivos.

${ }^{43}$ Sobre isso: FORTI, Iorio Siqueira D’Alessandri. O tribunal do júri como garantia fundamental, e não como mera regra de competência: uma proposta de reinterpretação do art. $5^{\circ}$, XXXVIII, da Constituição da República. Revista Eletrônica de Direito Processual - REDP, v 3, n 3, p. 1-19, 2009. 
Ainda que seja necessária a observância da duração razoável do processo, este direito não deve ser utilizado como fundamento para a violação de diversas outras garantias constitucionais e procedimentais que fazem parte da estrutura do devido processo legal afeto ao tribunal do júri, não podendo ser afastadas, nem mesmo em razão do cenário atual.

\section{EM BUSCA DE UMA SOLUÇÃO HARMONIZADORA: PRISÕES PREVENTIVAS, RAZOÁVEL DURAÇÃO DO PROCESSO E RAZOÁVEL DURAÇÃO DA CUSTÓDIA CAUTELAR}

Diante do impasse entre o fato de a proposta de realização de sessões virtuais ser contrária aos preceitos constitucionais, de um lado, e da não realização de sessões do tribunal do júri em virtude das medidas sanitárias gerar prejuízos, sobretudo aos acusados presos, de outro, é preciso refletir em busca de uma solução que harmonize tais circunstâncias.

Há diversos meios de garantir a duração razoável do processo, ou até mesmo minimizar os efeitos da pandemia ao réu que se encontra preso ou aguardando julgamento em liberdade. Como teoricamente alicerçado alhures, não é a realização da sessão do tribunal do júri de modo virtual que irá garantir ao réu a observância de todos os princípios basilares do procedimento especial.

Pensando nisso, apresenta-se como solução harmonizadora a possibilidade da revisão das prisões cautelares durante o período de pandemia, conforme os ditames da Recomendação n 62/2020 do CNJ, a qual traz a seguinte redação em seu art. $4^{\circ}$ :

Art. $4^{\circ}$ Recomendar aos magistrados com competência para a fase de conhecimento criminal que, com vistas à redução dos riscos epidemiológicos e em observância ao contexto local de disseminação do vírus, considerem as seguintes medidas:

I - a reavaliação das prisões provisórias, nos termos do art. 316, do Código de Processo Penal, priorizando-se:

a) mulheres gestantes, lactantes, mães ou pessoas responsáveis por criança de até doze anos ou por pessoa com deficiência, assim como idosos, indígenas, pessoas com deficiência ou que se enquadrem no grupo de risco; 
b) pessoas presas em estabelecimentos penais que estejam com ocupação superior à capacidade, que não disponham de equipe de saúde lotada no estabelecimento, que estejam sob ordem de interdição, com medidas cautelares determinadas por órgão do sistema de jurisdição internacional, ou que disponham de instalações que favoreçam a propagação do novo coronavírus;

c) prisões preventivas que tenham excedido o prazo de 90 (noventa) dias ou que estejam relacionadas a crimes praticados sem violência ou grave ameaça à pessoa;

II - a suspensão do dever de apresentação periódica ao juízo das pessoas em liberdade provisória ou suspensão condicional do processo, pelo prazo de 90 (noventa) dias.

Verifica-se que com a nova sistemática da Lei n ${ }^{\circ}$ 13.964/19 houve também a implementação da possibilidade de revisão da prisão preventiva quando decorrido o prazo de 90 (noventa) dias, conforme dispõe o art. 316, parágrafo único, do CPP. De fato, há diversas outras medidas que possibilitam ao réu proteção à saúde, sem que a demora no julgamento o prive de sua liberdade por tempo maior do que o devido e legalmente permitido.

Esse é um movimento legislativo que vem ocorrendo desde a reforma que introduziu a monitoração eletrônica no ordenamento jurídico brasileiro e remodelou as disposições sobre as medidas cautelares diversas da prisão, com a Lei $n^{0} 12.403 / 2011$. No entanto, o que se visualiza na praxe da área criminal é, em certa medida, uma resistência por parte de alguns julgadores e Tribunais em acolher essas modificações legislativas desencarceradoras, que constituem agendas de direitos humanos e fundamentais.

Ainda que o CNJ entenda pela possibilidade e viabilidade da realização das sessões do tribunal do júri de maneira virtual, há diversos questionamentos que acabam obstando a proposta, tal como a disponibilidade de instrumentos tecnológicos para o Conselho de Sentença, bem como a fiscalização acerca do sigilo das votações e a incomunicabilidade dos jurados.

Como fatos que acabam prejudicando o réu, eles possibilitam margem para argumentações no sentido de se buscar a anulação do júri, 
em virtude da inobservância das normas procedimentais. Por isso, não parece razoável permitir que o réu se submeta a tamanho ônus, quando o Poder Judiciário pode adotar medidas extraordinárias e efetivas, como por exemplo a suspensão das sessões, a revogação das prisões preventivas quando desnecessárias e a depender da natureza da infração penal, a fim de que não ocorram prejuízos para ambos os lados. Outro exemplo que pode ser extraído de medidas extraordinárias é a própria Recomendação $n^{\circ}$ 62/2020 do CNJ, a qual estabelece diversas orientações aos juízes singulares.

A Recomendação n ${ }^{0}$ 62/2020, exarada pelo CNJ, encontra largo amparo na doutrina, porquanto colige uma teia de princípios e ideários que representam, com precisão, os rumos que concretamente devem ser abraçados pelo sistema de justiça penal brasileiro, com a imposição de estrito acatamento do princípio da razoável duração da prisão cautelar.

Conquanto teoricamente a prisão figure como medida de extrema excepcionalidade ${ }^{44}$, faz-se necessário aplicar com mais intensidade as medidas cautelares diversas da prisão, previstas no art. 319 do CPP, bem como a substituição, sempre que viável, da prisão preventiva pela domiciliar - a qual poderá ser cumulada com as medidas cautelares já mencionadas -, por ser medida impositiva ao legítimo respeito ao princípio da razoável duração do processo ${ }^{45}$.

No cenário atual de pandemia, com inúmeras mortes e altíssimo grau de contaminação, deve-se pensar em medidas garantistas ${ }^{46} \mathrm{e}$ desencarceradoras, por se tratar de uma questão humanitária, e não em medidas que visam a uma "eficiência" a todo custo do sistema penal, como é o caso do júri virtual, ao atropelo dos preceitos constitucionalmente previstos, desconsiderando a formalidade que abraça o procedimento especial do júri e dando-lhe interpretações descompassadas com a legislação de regência.

44 PRADO, Luiz Regis; SANTOS, Diego Prezzi. Prisão preventiva: A contramão da modernidade. Rio de Janeiro: Forense, 2018, p. 111.

45 KARAM, Maria Lúcia. Prisão e liberdade processuais. Revista Brasileira de Ciências Criminais, São Paulo, v. 2, 1993, p. 87.

46 FERRAJOLI, Luigi. Garantismo: uma discussão sobre direito e democracia. Rio de Janeiro: Lumen Juris, 2012, p. 58. 
O ordenamento jurídico brasileiro, bem como a Recomendação $n^{0} 62 / 2020$ emanada pelo CNJ, permite a revisão das prisões preventivas que se encontrem em prazo excessivo de cumprimento, com o amparo de toda a legislação processual que propicia medidas desencarceradoras e acautelatórias, atingindo, portanto, sua finalidade precípua.

Não há, conforme a proposta de virtualização do júri do CNJ, a intenção de garantir o princípio da duração razoável do processo ao réu, mas tão somente acelerar as demandas do tribunal do júri, com o impacto da violação aos preceitos constitucionais pertinentes, o que deve ser coibido com veemência.

\section{Posicionamentos a favor da Realização da SESSÃo do TRIBUNAL DO JÚRI VIRTUAL}

Como se percebe, a pandemia trouxe diversos impactos - negativos e positivos - na justiça brasileira, considerando que esta teve que se adequar a situação excepcional que o país está enfrentando. Um dos grandes desafios, tanto para a efetivação da celeridade processual quanto para o cumprimento de metas do judiciário, foi a suspensão dos prazos e sessões do tribunal do júri.

Pode-se trazer que o posicionamento daqueles que advogam a favor da realização do tribunal do júri é sustentado no princípio da continuidade da prestação jurisdicional, o qual encontra-se previsto no artigo 93, inciso XII ${ }^{47}$. Inclusive, aos que se filiam a possibilidade da sessão do júri virtual, há como fundamento o artigo 185, § $2^{\circ}$, do Código de Processo Penal, o qual dispõe a possibilidade de o juiz realizar o interrogatório do réu por meio de sistema de videoconferência, em situações excepcionais. O argumento é de que a pandemia se tornou "situação excepcional" e a sessão virtual é medida apta a atender as finalidades do processo penal e seus princípios norteadores ${ }^{48}$.

47 ALMEIDA, Marcelo Pereira de. PINTO, Adriano Moura da Fonseca. Os impactos da pandemia de COVID 19 no Sistema de Justiça - algumas reflexões e hipóteses. Revista Juris Poiesis. Rio de Janeiro. Vol. 23 - n 31, pg. 01-15, 2020. $\mathrm{n}^{\circ}$ 83.318/RJ, Rel. Ministro Ribeiro Dantas, Quinta Turma, DJe 01/08/2017. 
Ao contrário dos que entendem pela impossibilidade da implantação sessão virtual, os apoiadores dessa medida extraordinária entendem que não haverá qualquer violação aos princípios processuais penais, visto que o acusado estará presente em todos os atos processuais, o que maximiza a sua participação e efetiva o contraditório e ampla defesa ${ }^{49}$. Sobre eventuais adaptações ao tribunal do júri, Aury Lopes leciona que:

É verdade que o Tribunal do Júri é cláusula pétrea da Constituição, art. $5^{\circ}$, XXXVIII, mas isso não desautoriza a crítica, pois o mesmo dispositivo consagra o júri, mas com a "organização que lhe der a lei”. Ou seja, remete a disciplina de sua estrutura à lei ordinária, permitindo uma ampla e substancial reforma, desde que assegurados o sigilo das votações, a plenitude de defesa, a soberania dos veredictos e a competência para o julgamento dos crimes dolosos contra a vida ${ }^{50}$.

De todo modo, é notório que nas sessões presenciais do júri há certa obstacularização quando uma testemunha não comparece, em razão de residir em comarca distante, como também a impossibilidade da presença do réu, ou vítima, ou do próprio defensor. São questões que podem ser, de certa forma, sanadas pela sessão virtual, ainda que somente no período da pandemia. Ora, a implementação da sessão através de videoconferência, por parte dos seus defensores, ocasiona maior celeridade processual e garante ao réu respeito às garantias constitucionais ${ }^{51}$.

Sabe-se que o processo penal é regido pelos princípios da publicidade, do contraditório e ampla defesa, os quais serão devidamente

49 CRUZ, Rogerio Schietti; LUNARDI, Fabrício Castagna; GUERREIRO, Mário Augusto Figueiredo de Lacerda. Tribunal do júri com apoio de videoconferência: pela ética do discurso. Consultor Jurídico, 2020. Disponível: <https://www. conjur.com.br/2020-jun-29/opiniao-tribunal-juri-apoio-videoconferencia>. Acesso em: 22 de jun. 2020.

50 LOPES JR., Aury. Direito processual penal. 17. ed. São Paulo: Saraiva, 2020, p. 471.

51 CRUZ, Rogerio Schietti; LUNARDI, Fabrício Castagna; GUERREIRO, Mário Augusto Figueiredo de Lacerda. Tribunal do júri com apoio de videoconferência: pela ética do discurso. Consultor Jurídico, 2020. Disponível: <https://www. conjur.com.br/2020-jun-29/opiniao-tribunal-juri-apoio-videoconferencia $>$. Acesso em: 22 de jun. 2020. 
efetivados com a realização da videoconferência. São diversas as vantagens trazidas pelos defensores do uso da sessão virtual, em que haverá, ainda, redução dos desgastes pelos jurados, os quais devem obrigatoriamente comparecer no fórum, ainda que não sejam escolhidos ${ }^{52}$.

Sobre isso, Schietti, Lunardi e Guerreiro apresentam algumas observações:

Lembre-se que, no sistema tradicional (em que há presença física das pessoas a serem ouvidas na instrução), durante a primeira fase do procedimento (sumário da culpa), vítima, testemunhas e réu podem ser ouvidos por carta precatória, ou seja, em juízo diverso daquele que julgará a causa. Vale dizer, sem o uso da videoconferência as presenças do réu e do seu advogado nas oitivas restam dificultadas (se o advogado não se deslocar para a outra comarca, é nomeado um defensor, que geralmente não tem contato com o réu, para acompanhar a oitiva). Com as audiências de instrução por videoconferência, o réu e o seu advogado ou defensor poderão estar presentes virtualmente em todas essas oitivas durante a instrução do processo ${ }^{53}$.

Como o tribunal do júri comporta todos os atos em uma sessão só, percebe-se que a celeridade do processo não será prejudicada. Sobre a celeridade do tribunal do júri, Goulart afirma que:

Embora a produção da prova em plenário importe necessariamente a realização de uma sessão mais demorada, o tempo de duração do trâmite processual será menor e, portanto, menos desgastante para acusado, vítimas e testemunhas, já que serão convocados uma única vez para a sessão de instrução e de julgamento ${ }^{54}$.

A concentração dos atos processuais viabiliza a celeridade sem perder a segurança jurídica do ato ${ }^{55} \mathrm{e}$, consequentemente, eventual sessão

52 Ibidem.

53 Ibidem.

${ }^{54}$ GOULART, Fábio Rodrigues. Tribunal do júri: aspectos críticos relacionados à prova. São Paulo: Atlas, 2008, p. 145.

55 SCHELEDER, Adriana Fasolo Pilati; FOLLE, Ana Júlia Cecconello. As novas tecnologias e a uniformização do processo eletrônico: vantagem e desvantagens. 
virtual não ocasionará qualquer óbice à ampla defesa e contraditório, pois ao acusado será possibilitado a presença em todos os atos, inclusive acompanhar os depoimentos das testemunhas e vítima.

Destarte os argumentos contra, é possível verificar que os defensores trazem soluções e argumentos aceitáveis e fortes, considerando que, de fato, o Poder Judiciário deve, constantemente, adequar-se às situações excepcionais, sem que isso ocasione atraso nas demais e no direito do réu em ter um devido processo legal e célere. A tecnologia vem ganhando força na atual era digital ${ }^{56}$, proporcionando que o acusado participe mais ativamente de todos os atos processuais, sem que isso lhe cause qualquer desgaste.

Não se pode deixar de afirmar que há diversos fatores que obstaculizam a celeridade processual, tal como a testemunha que reside em outra comarca, o defensor que não pode comparecer à audiência de instrução e julgado, e é nomeado defensor dativo - o que acaba prejudicando a ampla defesa do acusado -. São questão que podem ser resolvidas quando apresentada a possibilidade de sessão virtual do júri, considerando que ao acusado será possível participar de todos os atos processuais, bem como lhe será garantido defesa técnica e a publicidade do ato ${ }^{57}$.

\section{ConsideraçõEs finais}

Não obstante o momento de extrema excepcionalidade atravessado pelo mundo, diante das considerações e reflexões propostas neste texto, sustenta-se que o tribunal do júri virtual não é a melhor solução para a equalização entre evitar a paralisação da tramitação dos feitos e a necessidade de fidelidade aos preceitos jurídico-constitucionais que

Disponível em: <http://publicadireito.com.br/artigos/?cod=e3998932e2e851de>. Acesso em: 22 de dez. 2020.

56 ALMEIDA FILHO, José Carlos de Araújo. Processo Eletrônico e Teoria Geral do Processo Eletrônico. Rio de Janeiro: Forense, 2007, p. 12.

57 CRUZ, Rogerio Schietti; LUNARDI, Fabrício Castagna; GUERREIRO, Mário Augusto Figueiredo de Lacerda. Tribunal do júri com apoio de videoconferência: pela ética do discurso. Consultor Jurídico, 2020. Disponível: <https://www. conjur.com.br/2020-jun-29/opiniao-tribunal-juri-apoio-videoconferencia>. Acesso em: 22 de jun. 2020. 
envolvem a questão. Logo, diante de sua missão constitucional e democrática, se entende pela impossibilidade de mitigação do direito de defesa do réu, através da virtualização do procedimento especial.

Há outras resoluções para o problema que podem minimizar os danos causados pelo cenário pandêmico, sendo uma delas a revisão das prisões preventivas aos réus presos, com a aplicação, sempre que possível e dentro dos limites da Recomendação n ${ }^{0}$ 62/2020 do CNJ, de outras hipóteses legais como a prisão domiciliar e as medidas cautelares diversas da prisão.

Em resposta ao quesito introdutório, defende-se que, diante da problematização aqui exposta, o disposto no parágrafo anterior seria a possível forma de harmonizar soluções emergenciais advindas do contexto pandêmico com os preceitos constitucionais sobre o tribunal do júri, porquanto a virtualização do procedimento apresenta-se bastante temerária, ante a plausibilidade do raciocínio lógico-jurídico acerca de sua incompatibilidade com a CF e com as normas processuais, considerando a inobservância das regras trazidas ao procedimento especial do júri, bem como a impossibilidade de o CNJ dispor de tal modo sobre a matéria, em sede de processo penal.

Por isso, tal solução, ainda que sob o fundamento do princípio da duração razoável do processo, não merece prosperar, pois não se deve utilizar a justificativa da celeridade processual para violar as garantias individuais do júri que naturalmente servem de substrato ao acusado.

A solução mais adequada, atualmente, é aguardar que as sessões sejam realizadas, seguindo as orientações sanitárias, em um ambiente adequado e seguro para todos os presentes no momento, quando assim determinado pelas autoridades competentes, conferindo-se, neste período, os meios alternativos trazidos pela Recomendação nº 62/2020 do CNJ, como a revisão das prisões preventivas, a suspensão das sessões até que a situação se estabilize e aplicação da prisão domiciliar, quando preenchidos os requisitos.

Nos casos de extrema necessidade da manutenção da custódia cautelar, é possível que o Poder Judiciário adote providências extraordinárias, a fim de que o julgamento possa ser realizado de forma presencial, porém seguindo todas as orientações e instruções de saúde, tais como o distanciamento entre os presentes, o uso de máscaras adequadas, proteção 
facial de acrílico - face shield -, adoção de medidas de higiene por meio da disponibilidade de álcool $70^{\circ}$ INPM em gel, entre outras medidas sanitárias eficazes.

A melhor alternativa no momento atual é a adoção de medidas que, de fato, efetivem as garantias instituídas pelo tribunal do júri, não sendo a melhor alternativa a sua realização virtualmente. Os direitos e garantias fundamentais são muito caros para que se permita, em qualquer momento de excepcionalidade, seu vilipêndio, quando há soluções alternativas ao cenário apresentado.

As disposições constitucionais do tribunal do júri - art. $5^{\circ}$, inciso XXXVIII, alíneas a (plenitude de defesa), b (sigilo das votações), c (soberania dos veredictos) e d (competência para o julgamento dos crimes dolosos contra a vida), da CF/88 - ostentam aspecto substantivo, com íntima aproximação aos postulados da proporcionalidade e da razoabilidade, a demandar do Estado uma atuação pautada pela recomendação de posturas equilibradas entre a aplicação da lei penal e processual penal, a par de sua adequação às realidades e inovações sociais, mas sempre esgrimidas pela irradiação dos direitos fundamentais, a afastar, no caso, o aparente avanço tecnológico que se traduz em debilidade do procedimento especial.

\section{REFERÊNCIAS}

ALENCAR, Rosmar Rodrigues. Teoria da nulidade no processo penal. São Paulo: Noeses, 2016.

ALVES, Danielle Peçanha; MASTRODI NETO, José. Tribunal do júri e o livre convencimento dos jurados. Revista Brasileira de Ciências Criminais, v. 116, p. 1-19, 2015.

AMARAL, Sérgio Tibiriça; PEREIRA, Allan Aparecido Gonçalves. A arte do convencimento e o tribunal do júri. Revista Intertemas, v. 15, n. 15, 2008. Disponível em: <http://intertemas.toledoprudente.edu.br/index.php/Direito/article/ view/592>. Acesso em: 22 de dez. 2020.

ALMEIDA FILHO, José Carlos de Araújo. Processo Eletrônico e Teoria Geral do Processo Eletrônico. Rio de Janeiro: Forense, 2007. 
ALMEIDA, Marcelo Pereira de. PINTO, Adriano Moura da Fonseca. Os impactos da pandemia de COVID 19 no Sistema de Justiça - algumas reflexões e hipóteses. Revista Juris Poiesis, Rio de Janeiro, v. 23 - n³1, p. 01-15, 2020. Disponível em: <http:// periodicos.estacio.br/index.php/jurispoiesis/article/viewFile/8160/47966740>. Acesso em: 22 de jun. 2020.

BOBBIO, Norberto. Teoria do ordenamento jurídico. 6. ed. Trad. Maria Celeste C. J. Santos. Brasília: Editora Universidade de Brasília, 1995.

BULOS, Lammêgo Uadi. Constituição federal anotada. 4. ed. rev. e atual. São Paulo: Saraiva, 2002.

FERRAJOLI, Luigi. Garantismo: uma discussão sobre direito e democracia. Rio de Janeiro: Lumen Juris, 2012.

FORTI, Iorio Siqueira D’Alessandri. O tribunal do júri como garantia fundamental, e não como mera regra de competência: uma proposta de reinterpretação do art. $5^{\circ}$, XXXVIII, da Constituição da República. Revista Eletrônica de Direito Processual, v. 3, n 3, p. 1-19, 2009.

GARAPON, Antoine. Bem julgar: ensaio sobre o ritual judiciário. Lisboa: Instituto Piaget, 1997.

GOMES, Márcio Schlee. Sigilo das votações e incomunicabilidade: garantias constitucionais do júri brasileiro. Revista do Ministério Público, n. 67, p. 35-59, set. 2010.

GOULART, Fábio Rodrigues. Tribunal do júri: aspectos críticos relacionados à prova. São Paulo: Atlas, 2008.

KARAM, Maria Lúcia. Prisão e liberdade processuais. Revista Brasileira de Ciências Criminais, São Paulo, v. 2, 1993.

LOPES JR., Aury. Direito processual penal. 17. ed. São Paulo: Saraiva, 2020.

LUCINDO, Micheline Amorim. A incomunicabilidade dos jurados no tribunal do júri brasileiro. Monografia em Direito. Centro Universitário de Brasília (UniCEUB) Brasília, p. 1-54, 2009.

LIBER, Gabriel Henrique Araújo; RAINHO, Murilo Teixeira. Audiências virtuais na pandemia do coronavírus e seus reflexos no âmbito dos juizados especiais cíveis. ETIC, v. 16, n. 16, 2020. Disponível em: <http://intertemas.toledoprudente.edu. br/index.php/ETIC/article/view/8554>. Acesso em: 22 de dez. 2020.

MACIEL, José Fábio Rodrigues (coord.). Formação humanística em direito. São Paulo: Saraiva, 2012. 
MELCHIOR, Antonio Pedro. Crítica científica de "Redefinindo o trânsito em julgado a partir da soberania dos veredictos: a coisa julgada parcial no tribunal do júri". Revista Brasileira de Direito Processual Penal, Porto Alegre, vol. 6, n. 2, p. 1059-1078, mai./ago. 2020. https://doi.org/10.22197/rbdpp.v6i2.388

MONTEIRO, Paloma Abreu. O corpo nos rituais jurídicos: cultura, vestimenta e tatuagem nos tribunais do júri e varas criminais do Rio de Janeiro. Dissertação de mestrado. Programa de Pós-Graduação Stricto Sensu em Direito Constitucional da Universidade Federal Fluminense - PPGDC/UFF, 2015. Disponível em: <https:// app.uff.br/riuff/handle/1/6156 >. Acesso em: 22 de dez. 2020.

NADER, Paulo. Introdução ao estudo do direito. 36. ed. Rio de Janeiro: Forense, 2014.

NASCIMENTO, Joelson Santos. A relação entre lógica, páthos e ethos na arte retórica de Aristóteles. Anais de Filosofia Clássica, vol. 9, nº 17, 2015.

NICOLITT, André. Manual de processo penal. 7. ed. Belo Horizonte: Editora D’Placido, 2018.

NOVELINO, Marcelo. Direito constitucional. $3^{\circ}$ Ed. Rio de Janeiro: Forense, 2009.

NUÑEZ, Izabel; NEWTON, Eduardo Januário. O que será do tribunal do júri após a pandemia da covid-19? Consultor Jurídico. Disponível em: <https://www.conjur. com.br/2020-mai-12/newton-nunez-tribunal-juri-pandemia>. Acesso em: 26 jul. 2020.

OLIVEIRA, Heitor Moreira de; ATAÍDES, Maria Clara Capel de. Hermenêutica e Direito: Um olhar fenomenológico da performance. Anais do IV Congresso de Fenomenologia da Região Centro-Oeste (eixo temático 5: Fenomenologia, arte e cultura). Goiânia: NEPEFE/FE-UFG, vol. 1, n. 1. 2011. Disponível em: <https:// anaiscongressofenomenologia.fe.ufg.br/up/306/o/ComunHeitorMoreira.pdf $>$. Acesso em: 30 de jul. 2020.

PRADO, Luiz Regis; SANTOS, Diego Prezzi. Prisão preventiva: A contramão da modernidade. Rio de Janeiro: Forense, 2018, p. 111.

PERELMAN, Chaïm; e OLBRECHTS-TYTECA, Lucie. Tratado da argumentação: a nova retórica. Tradução: Maria Ermantina de Almeida Prado Galvão. São Paulo: WMF Martins Fontes, 2014.

PICCOLO, André Gustavo Bevilacqua. A supremacia da autodefesa: os limites da defesa técnica no processo penal constitucional. Revista da Defensoria Pública da União, v. 1, n. 1, 2018. Disponível em: <https://revistadadpu.dpu.def.br/index. php/revistadadpu/article/view/189>. Acesso em: 26 jul. 2020. 
PORTO, Hermínio Alberto Marques. Júri: procedimentos e aspectos do julgamento, questionários. 11. ed. São Paulo: Saraiva, 2005.

RANGEL, Paulo. Tribunal do júri: visão linguística, histórica, social e jurídica. São Paulo: Atlas, 2012.

RODRIGUES, Paulo Gustavo. Redefinindo o trânsito em julgado a partir da soberania dos veredictos: a coisa julgada parcial no tribunal do júri. Revista Brasileira de Direito Processual Penal, Porto Alegre, vol. 6, n. 2, p. 873-910, mai./ago. 2020. https://doi.org/10.22197/rbdpp.v6i2.301

SIMÃO, Diego de Azevedo. Júri por videoconferência é inconstitucional. Consultor Jurídico. Disponível em: <https://www.conjur.com.br/2020-jun-24/diego-simao-juri-videoconferencia-inconstitucional>. Acesso em: 26 jul. 2020.

STRECK, Lenio Luiz. Jurisdição constitucional e hermenêutica: uma nova crítica do direito. 2. Ed. Rio de Janeiro: Forense, 2004.

SCHELEDER, Adriana Fasolo Pilati; FOLLE, Ana Júlia Cecconello. As novas tecnologias e a uniformização do processo eletrônico: vantagem e desvantagens. Disponível em: <http://publicadireito.com.br/artigos/?cod=e3998932e2e851de>. Acesso em: 22 de dez. 2020.

TÁVORA, Nestor; ALENCAR, Rosmar Rodrigues. Curso de direito processual penal. 14. ed. Salvador: JusPodivm, 2019.

TUBENCHLAK, James. Tribunal do júri: contradições e soluções. 3. ed. Rio de Janeiro: Forense, 1991.

VASCONCELLOS, Vinicius Gomes de; GALÍCIA, Caíque Ribeiro. Tribunal do júri na justiça criminal brasileira: críticas e propostas de reforma para a restituição de sua função de garantia no processo penal democrático. Revista Eletrônica de Direito Processual, v. 13, n. 13, p. 1-28, 2014. 


\section{Informações adicionais e declarações dos autores (integridade científica)}

Declaração de conflito de interesses (conflict of interest declaration): os autores confirmam que não há conflitos de interesse na realização das pesquisas expostas e na redação deste artigo.

Declaração de autoria e especificação das contribuições (declaration of authorship): todas e somente as pessoas que atendem os requisitos de autoria deste artigo estão listadas como autores; todos os coautores se responsabilizam integralmente por este trabalho em sua totalidade.

- Ronald Pinheiro Rodrigues: projeto e esboço inicial (conceptualization), desenvolvimento da metodologia (methodology), coleta e análise de dados (data curation), levantamento bibliográfico (investigation), revisão bibliográfica (investigation), redação (writing - original draft), participação ativa nas discussões dos resultados (validation), revisão crítica com contribuições substanciais (writing - review and editing), aprovação da versão final.

- Nigel Stewart Neves Patriota Malta: projeto e esboço inicial (conceptualization), desenvolvimento da metodologia (methodology), coleta e análise de dados (data curation), levantamento bibliográfico (investigation), revisão bibliográfica (investigation), redação (writing - original draft), participação ativa nas discussões dos resultados (validation), revisão crítica com contribuições substanciais (writing - review and editing), aprovação da versão final.

Declaração de ineditismo e originalidade (declaration of originality): o artigo aqui publicado foi deposita em 22.9.2020 como preprint (https://doi.org/10.1590/SciELOPreprints.1174); futura republicação somente se realizará com a indicação expressa da referência desta publicação original; também atestam que não há plágio de terceiros ou autoplágio. 


\section{Dados do processo editorial}

(http://www.ibraspp.com.br/revista/index.php/RBDPP/about/editorialPolicies)

- Recebido em: 04/08/2020

Equipe editorial envolvida

- Controle preliminar e verificação de plágio: 05/08/2020

- Retorno rodada de correções 1: 12/08/2020

- Editor-chefe: 1 (VGV)

- Revisores: 4

- Depósito preprint: 22/09/2020 (https://doi. org/10.1590/SciELOPreprints.1174)

- Avaliação 1: 13/09/2020

- Avaliação 2: 13/09/2020

- Avaliação 3: 15/09/2020

- Avaliação 4: 23/09/2020

- Decisão editorial preliminar: 02/11/2020

- Retorno rodada de correções 1: 25/01/2021

- Decisão editorial preliminar 2: 27/01/2021

- Retorno rodada de correções 2: 09/02/2021

- Decisão editorial final: 18/02/2021

\section{COMO CITAR ESTE ARTIGO:}

RODRIGUES, Ronald P.; MALTA, Nigel S. Tribunal do júri virtual: em busca da harmonização entre as soluções emergenciais ocasionadas pela pandemia do novo coronavirus e a observância dos preceitos constitucionais. Revista Brasileira de Direito Processual Penal, Porto Alegre, vol. 7, n. 1, p. 475-508, jan./abr. 2021. https://doi.org/10.22197/rbdpp.v7i1.439

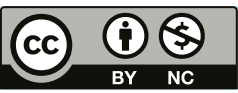

Esta obra está licenciada com uma Licença Creative Commons Atribuição-NãoComercial 4.0 Internacional. 